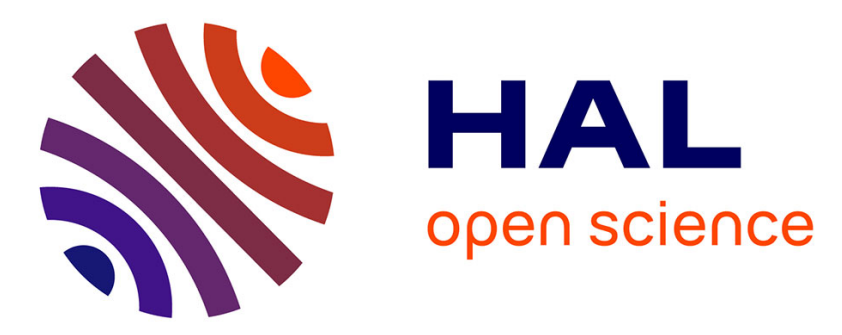

\title{
Effects of crop management and surrounding field environment on insect incidence in organic winter oilseed rape (Brassica napus L.)
}

Muriel Morison, Jean Marc Meynard, Thierry Doré

\section{- To cite this version:}

Muriel Morison, Jean Marc Meynard, Thierry Doré. Effects of crop management and surrounding field environment on insect incidence in organic winter oilseed rape (Brassica napus L.). Crop Protection, 2007, 26 (8), pp.1108-1120. 10.1016/j.cropro.2006.10.005 . hal-01173123

\section{HAL Id: hal-01173123 \\ https://hal.science/hal-01173123}

Submitted on 13 Aug 2019

HAL is a multi-disciplinary open access archive for the deposit and dissemination of scientific research documents, whether they are published or not. The documents may come from teaching and research institutions in France or abroad, or from public or private research centers.
L'archive ouverte pluridisciplinaire HAL, est destinée au dépôt et à la diffusion de documents scientifiques de niveau recherche, publiés ou non, émanant des établissements d'enseignement et de recherche français ou étrangers, des laboratoires publics ou privés. 


\title{
Effects of crop management and surrounding field environment on insect incidence in organic winter oilseed rape (Brassica napi)
}

\author{
Auteurs: M. Valantin-Morison1*, J-M MeYnARD2, T. DORE3 \\ 1- INRA, UMR d'Agronomie INRA/INA P-G, B.P. 01, F-78850 Thiverval-Grignon, tel 01308154 31, fax 01
} 30815425 ;

2- INRA, Département «Sciences pour l’Action et le Développement », B.P. 01, F-78850 Thiverval-Grignon

3- INA P-G, UMR d'Agronomie INRA/INA P-G, B.P. 01, F-78850 Thiverval-Grignon.

* Corresponding author

\begin{abstract}
Many organic farmers hesitate to grow winter oilseed rape (WOSR), despite its usefulness for crop rotations and animal fodder, because it is attacked by many insects, which are difficult to control without chemical treatments. In a geographically broad network of farmer's fields, we analyzed the effect of various crop management factors and of the surrounding field environment on a large range of insects known to damage WOSR: root maggot (Delia radicum L.), cabbage stem flea beetle (Psylliodes chrysocephala L.), rape stem weevil (Ceuthorhynchus napi Gyl) and pollen beetle (Meligethes aeneus F.). Our results confirm the effect of sowing date, plant density and soil tillage regime on root maggot attacks and cabbage stem flea beetle larva infestation. Early sowing tended to increase root maggot damage whereas it was associated with a lower level of attack of cabbage stem flea beetle. High plant density tended to decrease the damage or the attack of all insects. We show that nitrogen availability in the soil affect cabbage stem flea beetle, stem weevil levels and pollen beetle damage : the negative effect of soil nitrogen content on pollen beetle damage may be related to the significant effect of nitrogen on plant vigour and, therefore, to the compensation of pollen beetle damage on new racemes. If all insects were considered together, the proportion of land under WOSR in the region and the surrounding environment had a significant effect on pest occurrence. In regions with a high proportion of land under WOSR, the proportion of plants attacked by root maggot and pollen beetle tended to increase. Conversely, regions with high proportions of land under WOSR tended to have a smaller proportion of plants with cabbage stem flea beetle larvae or damage, whatever the environment surrounding the field. For almost all the pests considered, the fields displaying the most severe pest attacks in regions with more than $1.2 \%$ WOSR were bounded by trees, hedges and bushes. Conversely, in regions with a lower percentage of land under WOSR, woodland around the field reduced the occurrence of pest attacks.
\end{abstract}


Key words: winter oilseed rape; organic farming; crop management; insects; field boundaries. 


\section{Introduction}

One of the key tenets of organic farming is the efficient management of crop protection against pests, based on an understanding of the biology of the organisms in relation to cropping systems and the surrounding landscape. Winter oilseed rape (WOSR) is particularly useful for in crop rotations and animal fodder, but organic farmers hesitate to grow it because it is attacked by numerous insects (Alford et al., 2003), which are difficult to control without chemical treatments. No extensive study has investigated the effects of crop management on WOSR in organic systems, accounting for the current lack of pesticide-free crop-protection strategies for this crop. Furthermore, the emergence of insect resistance to the pesticides used and decreasing profit margins and environmental concerns, have also made the incidence of pests and pest management key issues in conventional WOSR farming. A few recent studies have investigated the effect of crop management systems in conventional farming (Dosdall et al., 1996, 1998; Barari et al., 2005; Williams et al., 2002, 2006)

In France, with the exception of root maggot (Delia radicum L.), a dipteran, and pod midge (Dasineura brassicae Winn.), a hymenopteran, the main insect pests damaging WOSR belong to the Coleoptera. The principal coleopteran pests are cabbage stem flea beetle (Psylliodes chrysocephala L.), rape stem weevil (Ceuthorhynchus napi Gyl), pollen beetle (Meligethes aeneus F.), and seed weevil (Ceuthorhynchus assimilis Gyl.). Aphids (Brevicoryne brassicae L.) are also a problem in regions of the south of France. In this study, we investigated the effect of crop management systems on root maggot, cabbage stem flea beetle, rape winter stem weevil and pollen beetle.

Root maggot larvae feed on root tissue during the autumn, causing primary damage by root destruction and secondary damage when feeding channels are subsequently invaded by root rot fungi. In conventional farming, seed treatment with insecticides limit the spread of this insect. The effects of crop management systems on root maggot have been studied in more detail. Dosdall et al. $(1996,1998)$ have extensively investigated the effects of sowing date, plant density and soil tillage 
on emergence, infestations and egg production in Delia spp. The susceptibility of various cultivars or Brassicaceae species to infestations has also been assessed (Birsh et al., 1992; Dosdall et al., 1994, 2000). Oilseed rape was the crop most susceptible to root maggot, whereas Sinapis alba was the least susceptible. Susceptibility differed more between species than between cultivars of the same species, and these differences may be related to glucosinolate content (Dosdall et al., 2000).

During the autumn, cabbage stem flea beetle larvae feed on the inside of petioles, leaf veins and stems. The damage they cause has been studied in conventional farming and this insect can be contained by use of the appropriate chemical insecticides. However, alternatives to chemical insecticides for use in organic farming have received little attention and are currently not effective enough. The extent of damage caused by cabbage stem flea beetle differs between cultivars (Bartlet et al., 1996), and zero tillage systems slightly decrease the level of larval infestation (Ulber and Schierbaum-Schickler, 2002), but the possible effects of other elements of crop management have not been studied. Studies carried out in continental Europe have shown that the larvae of stemmining pests are attacked by the parasitoid species Tersilochus tripartitus and Tersilochus microgaster (Ulber, 2000; Williams et al., 2002). Barari et al. (2005) showed that the turnip rape (Brassica rapa), grown in crop borders as a "trap" crop, can reduce infestations of cabbage stem flea beetle, also trapping the parasitoids associated with this pest.

During spring, two insects are the most damaging pests of WOSR in conventional conditions in France : pollen beetle and rape stem weevil. Adult pollen beetles, attracted by visual cues from the crop, feed on pollen and oviposit in blooming flowers, causing bud abscission. However, pollen feeding in open flowers rarely causes abortion and subsequent yield loss. The emergence of pyrethrinoid resistance in pollen beetle has made it difficult to contain this insect, even in conventional systems (Ballanger et al., 2002 ; Hansen, 2003 ; Ekbom and Kuusk, 2001). No natural insecticide against pollen beetle is authorized for use in organic farming in France. However, a strain of Metarhizium anisopliae is highly pathogenic to pollen beetle (Butt et al., 1992 ; Butt et al., 1998 ; Husberg and Hokkanen, 2001). The effects of crop management systems (plant density, 
sowing date, soil tillage regime) on feeding behaviour and larval infestation with rape stem weevils and pollen beetle have not been studied. However, based on the hypothesis that the production of glucosinolates by cultivars of WOSR and other Brassicaceae may attract pollen beetle, many studies have focused on the effects of host plants on insect orientation and feeding (Bartlet et al., 2004), oviposition behaviour (Borg and Ekbom, 1996), and egg production in pollen beetle (Hopkins and Ekbom, 1999). Turnip rape has been found to attract pollen beetle in both laboratory and field conditions (Nilsson, 1994; Hokkanen et al., 1986; Hokkanen, 1989; Cook et al., 2002). Parasitoids and predators of pollen beetle have also been identified (Büchi, 2002; Nielsen and Philipsen, 2005) and these species also seem to be attracted by the host plant (Billqvist and Ekbom, 2001a,b). The environment around the field affects pollen beetle mortality due to predator activity (Büchi, 2002).

Rape stem weevil females lay their eggs in the stem in March and April, deforming the stem considerably, and thereby damaging the crop. It is possible to contain rape stem weevil with chemicals, if the treatment is applied at the appropriate time. Very few studies have focused on the effect of cropping systems or field boundaries on rape stem weevil infestations.

A global crop management approach to the control of a wide range of insects is now required for the establishment of a chemical-free crop protection system for organic farming. Previous studies dealing with the effects of cropping systems or the surrounding environment on insects infesting oilseed rape have focused on one pest in one region. In addition, some insects, such as stem weevils, have received very little attention. The effect of cultivar has frequently been assessed whereas the effects of other elements of crop management, such as sowing date, nitrogen supply, row spacing and plant density, have rarely been considered. The aim of this study was to analyze, in a broad network of organic farmer's fields, the effect of diverse crop management factors and of the environment surrounding the field on a broad range of insects known to damage WOSR.

Crop management affects insect damage, by modulating plant growth and phenology. Variability in plant architecture in the crop may affect the clustering of hosts, which may display a 
patchy distribution, thereby also affecting food seeking efficiency and oviposition behaviour in the pest. Seedling rate and row spacing may affect crop growth and climatic microenvironment. By manipulating sowing date, it may be possible to create asynchrony between crop and pest phenology. Soil tillage regime may also have an effect. Previous studies have shown that soil cultivation can affect populations of insects spending part of their life cycle in the soil (Stinner and House, 1990) and also the parasitoïds of these insects (Hokkanen et al., 1988). But the broad generalizations are inappropriate when describing the effects of tillage regime on insects. Soil management before sowing may affect the physical properties of the soil, such as soil moisture, organic matter content, soil temperature and the presence of a barrier to reproduction or feeding. These changes may render the soil more or less favourable for oviposition, depending on the life cycle of the insect. We tested hypotheses of this type for two pest species, but did not assess the effect of soil tillage for the two spring pests, as it was not thought to be relevant given the life cycle of these pests.

The hypothesis concerning the field environment focused on the proportion of land in the region under WOSR and the presence of natural habitats around the field (meadow, hedges, forest) that might affect the insect populations. Many studies have shown that field margins and conservation strips are the preferred overwintering sites of predators of pests (Dennis 1992; Franck, 1998; Büchi, 2002). For example, pollen beetles overwinter as adults in wooded areas rich in humus. At the end of winter, attracted by visual and volatile chemical cues (Bartlet et al., 2004) from brassicas, mature adults fly to host plants, searching for pollen (life cycle described by Büchi, 2002). Thus, the environment around the field, which may constitute an overwintering site, has the potential to influence the population of adult WOSR pests and their predators and parasitoids. We tested this second set of hypotheses on root maggot or cabbage stem flea beetle and on rape winter stem weevil and pollen beetle. 


\section{Materials and methods}

\section{1. Study area and experimental design}

We studied 56 plots on 22 fields on 15 farms (Table 1) from four regions with contrasting climatic conditions, distributed all over France. This study covered a three-year period (year of harvest 2001-2002-2004). Three farms were studied at least two successive years, but experiments were not displayed in the same field all along the 3 years. Each plot was located on a homogeneous area of the field in soil texture and soil depth and their dimensions ranged from $6000 \mathrm{~m}^{2}$ to $1200 \mathrm{~m}^{2}$. Several plots could have been placed in the same field. The plots differed in terms of crop management but not all the plots were studied every year. Plots were designated with a letter-figureletter code, in which the first letter is the field code and the figure, a composite of the year code (01, 02, 04 for 2001, 2002 and 2004 respectively) and the little letter the crop management code (for example -a and -b corresponding to different sowing dates). Crop management systems differed in terms of sowing date, plant density, soil tillage and row spacing and are detailed in the table 2. Farms $\mathrm{A}$ to $\mathrm{E}$ are located in the centre of France (Puy-de-Dôme). Fields $\mathrm{F}$ to $\mathrm{K}$ are located in southern France (Drôme and Gard). Fields lettered L, M, N, T, U are located in the south-western of the Parisian Basin (Eure, Eure-et-Loir), and those lettered from $\mathrm{O}$ to $\mathrm{S}$ are located in the southeastern Paris Basin (Yonne). Field size ranged from 1 to 11 ha.

Pest incidence has been reported to be affected by surrounding environment and five crop management factors (soil tillage regime, sowing date, plant density, row spacing, and cultivar). The network of fields was set up to test the effects of these factors on pest incidence, selecting the plots studied according to the hypothesis tested.

We tested the crop management hypothesis on all plots in our network planted with the same cultivar, for each year (Navajo in 2000, Pollen in 2001 and Mendel in 2003). These plots differed in sowing date, plant density, soil tillage regime and soil nitrogen content at sowing. The fields studied were: A01, B01, B02, B04, C01, D01, E01, E02, K01, I01, J01, L02, L04, M02, N02, O02, P02, Q02, R04, S04, T04 and U04, comprising 56 plots. 
We tested the environment hypothesis on plots with similar soil tillage (ploughing) and the same sowing date (from 25 August to 5 September). These plots differed in surrounding environment and percentage of land under WOSR in the region. Fields were classified as "woodland" if the field was in farmland surrounded and criss-crossed by hedges and trees or "plain" if the farmland for $500 \mathrm{~m}$ around the field contained no trees or hedges. The fields and plots studied were B04-c-d-g-h, E01 g, I01g, J01g, L02 b-c-h, L04 c-d-g-h, N02 c-d, P02 c-d, R04 b-c-d-g-h, S04 c-d-g-h, T04 c-g and U04 $\mathrm{c-g}$, comprising 31 plots.

\subsection{Measurements and observations}

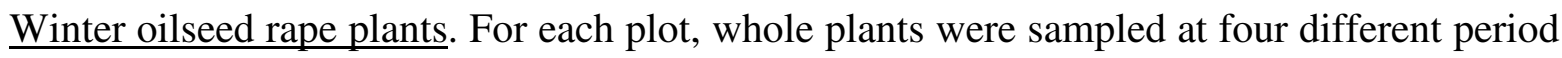
of the year: (i) in early winter, before winter drainage and the occurrence of cold temperatures (early November in northern France and early December in southern France), (ii) in late winter (end of January in the south and mid-February in the north), (iii) early blooming (F1 stage- beginning of April), and (iv) pod filling (G5 stage - beginning of June). In each field, at each stage, samples were taken from $8(2001)$ or $6(2002,2004) 0.5 \mathrm{~m}^{2}$ microplots. The plants were counted and the roots separated from the aerial parts after washing. For each microplot sample, dry biomass (after $48 \mathrm{~h}$ of drying at $80^{\circ} \mathrm{C}$ ) and total nitrogen content of green aerial parts and tap roots (Dumas method) were determined. During autumn and winter, the numbers of leaf scars on the stem and of remaining green leaves were counted on 15 randomly chosen plants per microplot. At early winter the collar diameter was measured thanks to a numerical calliper. At the pod-filling stage, the number of branches and the height of the plant were determined for 10 randomly chosen plants per microplot.

Soil: Soil and subsoil mineral nitrogen amounts were determined by colorimetry after extraction in a solution of $1 \mathrm{~N} \mathrm{KCl}$, approximately one month after sowing and on the same dates as plant sampling.

$\underline{\text { Pests and diseases: }}$ Crop attacks by insects were estimated from 15 randomly chosen plants per microplot, in both autumn and winter. In autumn, we counted the proportion of plants with root maggot damage; we also determined the proportion of plants harbouring cabbage stem flea beetle 
larvae. At flowering, we determined the proportion of plants displaying rape stem weevil damage or harbouring the larvae of this pest, on 10 randomly sampled plants per microplot. Three measurements were made for pollen beetle : the proportion of plants with larvae, the proportion of plants with adults and the proportion of short peduncles without pods, which are more commonly called 'blind stalks'. At flowering, we determined the proportion of plants with pollen beetle larva, by dissecting all the buds and flower of 10 plants randomly chosen in the microplots, already sampled for the other measurements. In the last year, 3 weeks before flowering, at 16 places in the field, 5 neighbour plants were cut at their base and were quickly bagged together in one bag. The sixteen bags per field were placed in a cold chamber $\left(-4^{\circ} \mathrm{C}\right)$ to kill the insects. We then counted the number of adult pollen beetles on these 16 samples of 5 plants. At the pod-filling stage, we estimated damage to the crop due to spring insects. We counted the number of short peduncles without pods from 10 randomly sampled plants per microplot. This measure provided information about bud abortion linked to the incidence of pollen beetle damage (CETIOM, 1994).

\subsection{Statistical analysis}

Normal-theory statistical analysis was used on continuous variables, such as dry biomass, applying standard analysis of co-variance procedures. Proportions, such as the proportion of plants

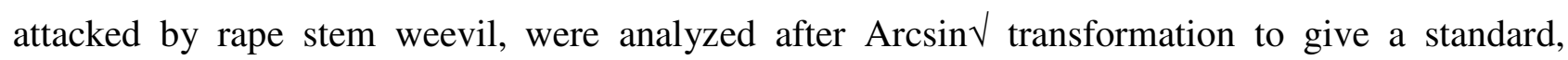
uniform variance for all groups. An analysis of covariance has been done to test the effect of crop management and of surrounding environment. The treatments of this analysis were constituted by the date of sowing and the soil tillage regime. Because of some problems at the plant emergence, the objective of plant density has not been realized every where. Consequently, plant density has not been considered as a treatment but the measurements have been introduced as a covariate in the analysis. Similarly for nitrogen in the soil one month after sowing. The "site year effect" is a way to describe the differences between the year and the regions : one year and one region constitute one site-year ; there were 8 different site-year. For the environment hypothesis, plant density and soil 
nitrogen content were introduced into the ANOVA as covariables after the demonstration of a significant effect for the first set of hypotheses.

\section{Results}

\subsection{Insect incidence and damage in the field network}

Root maggot attacks varied little by region and year. They were systematically severe in the centre of France and the eastern Parisian Basin: the level of root maggot attacks ranged from $27 \%$ to $35 \%$ in the three years. In the western Parisian Basin, the levels of this insect varied between years, and the occurrence of this insect was lowest in southern France (Table 3).

The occurrence of cabbage stem flea beetle was highly variable and depended on the region and the year (Table 3), with plots in the South of France displaying a particularly high level of attack ( $73 \%$ of plants with at least one larva). In the eastern and western Parisian Basin, the occurrence of cabbage stem flea beetle depended on the year: $19 \%$ of plants with larvae in the west and $7 \%$ in the east the first year, versus $97 \%$ of plants attacked in 2003-2004. In central France, the occurrence of this insect ranged from $16 \%$ to $33 \%$ over the three years.

The occurrence of rape stem weevil (C. napi) varied more between years than between regions (Table 3). Rape stem weevil attacks were severe in the central and southern France, with $35 \%$ to $98 \%$ of plants attacked in the three years in central France. The occurrence of this pest was $20 \%$ to $36 \%$ in the eastern Parisian Basin.

For pollen beetle, table 3 shows the proportion of plants with at least one adult or one larva at the beginning of flowering, the number of adults per plant at the beginning of flowering and the proportion of buds aborted due to this insect, corresponding to damage. In central France, a high percentage of plants were infested with pollen beetle $(78 \%)$, but the small number of adults per plant (0.6) resulted in a low level of damage (14\% of flowers aborted). In the western Parisian Basin, $90 \%$ of plants were attacked, with 3.1 adults per plant, resulting in the abortion of $13 \%$ of flowers, whereas in the eastern Parisian Basin, $90 \%$ of plants were attacked, with 6.5 adults per plant, resulting in the abortion of $35 \%$ of flowers. Based on damage assessment, attacks were severe 
in all regions in 2001-2002 (from 27 to $40 \%$ of flowers aborted due to pollen beetle damage), and pollen beetle seemed to be a particular problem in the eastern Parisian Basin, with more than $30 \%$ of flowers damaged.

\subsection{Effect of crop management on pest insects}

3.2.1. Effect of sowing date, sowing density and nitrogen availability during autumn on Delia radicum L, Psylliodes chrysocephala L. Ceuthorhynchus napi Gyll and Meligethes aeneus F.

Sowing date, plant density and soil nitrogen content had significant effects on the percentage of plants attacked by root maggot (Table 4). Early sowing tended to increase root maggot damage (Figure 1A) whereas high plant density tended to decrease this damage. Plants attacked by root maggot had a larger collar diameter than healthy plants (Figure 2A).

Sowing date, soil nitrogen content at sowing and plant density in early winter affected the proportion of plants with at least one cabbage stem flea beetle larva (Table 4). Early sowing was associated with a lower level of attack (Figure 1B), whereas high plant density was associated with the lowest frequency of cabbage stem flea beetle attacks. However, none of the plant characteristics assessed that might have been modified by cropping practices, such as collar diameter, number of leaves and number of scars, differed significantly between healthy and attacked plants (data not shown).

Sowing date and soil nitrogen content at sowing had a significant effect on the proportion of plants with symptoms of rape stem weevil attack or larvae of this insect at flowering (Table 4). None of the plant characteristics assessed (height, number of branches) differed significantly between healthy and attacked plants.

Only soil nitrogen content at sowing and plant density had significant effects on the proportions of flowers potentially destroyed by pollen beetle (Table 4). Similarly as cabbage stem flea beetle and stem weevil, high plant density was associated with lower damage of pollen beetle. Sowing date had no significant effect. We also found that, on a given plot, plants with at least one larva present in the flowers were a few centimetres higher than plants with no larvae (Figure 2B). 


\subsubsection{Effect of soil tillage regime on Delia radicum L. and Psylliodes chrysocephala L.}

Soil tillage regime affected the occurrence of cabbage stem flea beetle larvae in plants and the occurrence of damage due to root maggot (Table 4). Cabbage stem flea beetle larval infestations were smaller in a shallow tillage regime than under ploughing (Figure 1C), whereas the observed level of root damage was slightly higher (not illustrated) on plants grown in the shallow tillage system, with the exception of those grown on plots in central France in 2001.

Although significant effects of cropping practices were identified, the proportion of the variance accounted for by these effects was much smaller (Table 4: from 0.02 to $9.1 \%$, depending on the insect and crop management system considered) than the site-year effect (Table 4: from $8.1 \%$ to $63.5 \%$ depending on the insect species considered). Thus, the location of the field and the climatic conditions of the year resulted in a high level of variability in the occurrence of insects. The site effect was therefore described by two variables: percentage of land under WOSR in the region and presence of woodland around the field.

\subsection{Effect of the environment surrounding the field on pest insects}

We assessed the effect of the percentage of land under WOSR in a region and of the presence or absence of trees, hedges and woodland in the field boundaries on the occurrence of pests (Table 5). Covariables, such as soil nitrogen content at sowing and plant density, which were found to have an effect in the previous analysis (Table 4) were introduced into the ANOVA (table 5). Differences in the data used (analysis of different plots), the proportion of the variance accounted for by these covariables differed in the two analyses (tables 4 and 5), but the sign of the regression coefficient was similar. Figure 4 shows the direction of variation of the effects of percentage of land under WOSR in a region and surrounding environment.

For all pests, the year effect was significant but accounted for a smaller proportion of the variance than the site-year effect observed in table 4. For all insects considered together, the percentage of land under WOSR in the region and the surrounding environment had a significant effect on pest occurrence (Table 5). The factor accounting for the largest proportion of the variance was the percentage of land under WOSR in the region for cabbage stem flea beetle (25.3\%), 
whereas it was the environment surrounding the field for root maggot $(28.3 \%)$. This suggests that the characteristics of field boundaries were correlated with crop damage for this pest. The environment surrounding the field had very little effect on rape stem weevil attacks (accounting for $0.9 \%$ of the variance), but had a significant effect on crop damage due to pollen beetle (48.4\%).

The proportion of land under WOSR in a region was positively correlated with the proportion of plants attacked by root maggot (Figure 3A) and pollen beetle (Figure 3D). Conversely, the percentage of land under WOSR in a region was negatively correlated with the proportion of plants with cabbage stem flea beetle larvae or damage, whatever the surrounding environment of the field (Figure 3B). The percentage of land under WOSR had an effect on rape stem weevils attacks (figure 3C) in fields with no surrounding trees, hedges or bushes, consistent with the small proportion of the variance accounted for by this factor in table 5 .

For almost all the pests, the fields with the most severe attacks were bounded by trees, hedges and bushes in regions in which more than $1.2 \%$ of the land was under WOSR. In contrast, in regions with a lower proportion of land under WOSR, the presence of trees, hedges and bushes around the field reduced the occurrence of the attacks. For cabbage stem flea beetle, the environment surrounding the field had no effect in regions with a high proportion of land under WOSR, whereas it had a significant effect in regions with a low proportion of land under WOSR. This may account for the very small proportion of the variance accounted for by surrounding environment in table 5 .

\section{4- Discussion}

In our study, the main effect was the site-year effect. The year effect could not be separated from the cultivar effect in our database, because we chose not to study the cultivar effect, which has already been widely investigated. However, many elements of crop management appeared to have a significant effect on the occurrence and severity of damage. This may facilitate the establishment of a pesticide-free crop management system. 


\subsection{Effect of crop management}

The effect of sowing date on root maggot levels could be accounted for by effects on the synchrony of the life cycle of the root maggot and crop phenology. Females lay their eggs in the soil, at the base of the plant stem, from April until the end of September (Alford et al., 2003), producing three to four cohorts of adults. Plants sown early in August were therefore more likely to be damaged by adult root maggots than plants sown later, during September. The relationship between collar diameter and the occurrence of damage on plants in this study suggests that females select plants with larger stem bases for oviposition. These results are consistent with those of Dosdall et al. (1996) for oilseed rape, showing that basal stem diameter and root damage ratings are correlated. Dosdall et al. also showed that root maggot infestations were reduced by sowing in late May rather than mid May and by high sowing density. The effect of nitrogen availability at sowing on pest damage reported here has not previously been described, but may be related to plant growth status. It could be argued that the concordance of plant and pest phenology, and the attractiveness of the plant are the key elements that could be modulated to manage root maggot damage: this insect lays its eggs in plots sown early and females prefer plants with large collar diameters. The effect of tillage regime on Delia radicum L. was investigated by Dosdall et al. (1998) for oilseed rape. They found that root maggot egg populations were larger and root damage was more severe with a zerotillage regime than with a conventional tillage regime. Dosdall defined conventional tillage as shallow tillage without ploughing. Dosdall et al. (1998) suggested that these differences between the two tillage regimes might result from microclimatic differences: zero-tillage systems are characterized by higher soil moisture and organic matter contents than conventional tillage systems (Holland, 2004), resulting in more favourable conditions for the oviposition of this pest. We compared shallow tillage without ploughing and ploughing. Deep ploughing is known to modify soil structure considerably and to be one of the most disturbing agricultural practices for soil fauna. In our study, plots with shallow tillage displayed higher levels of pest attack than plots with ploughing. These findings are consistent with the work of Dosdall et al. (1998). 
Early sowing was associated with lower levels of cabbage stem flea beetle attack, possibly due to the life cycle of this insect. Adult beetles invade the crop in mid-September and October and attack newly emerged seedlings by chewing pits in the cotyledons, leaves and stems. Females lay their eggs in the soil from late August onwards and the emerging larvae bore into the petioles and mine the leaves and stems (Alford et al., 2003). If the crop was sown early in August, the chewing of the leaves is harmless and larvae appear in the petioles of leaves that will fall earlier before winter. The effects of sowing date, plant density and soil nitrogen content at sowing on cabbage stem flea beetle have not previously been described. However, Dosdall et al. (1999) assessed the effect of row spacing and seedling rate on feeding damage by other flea beetles (Phyllotreta spp.) in oilseed rape. They reported that increasing plant density and widening row spacing in oilseed rape crops were associated with lower levels of seedling damage by flea beetles. Our results are consistent with these observations on oilseed rape and other species of flea beetles, as the coefficient of regression generated by ANOVA was negative for plant density. Nevertheless, it is difficult to know whether this effect of high plant density could be due to changes in the microclimate or in the structure of the crop. It could also be due a dilution of the numbers of pests present rather than to a lower attractivity of the crop. In order to investigate this hypothesis, specific experiments should have been done and measurements of the number of larvae in the plants all along autumn should have been made. There have been few studies of the effects of tillage regime on cabbage stem flea beetle. However, Ulber and Schierbaum-Schickler (2002) reported in a short communication that the number of stem flea beetles colonizing the crop and the level of larval infestation were significantly higher in conventionally ploughed plots than in plots subjected to conservation tillage or direct drilling, consistent with our results. Another study on other flea beetle species (Phyllotreta spp) in oilseed rape (Dosdall et al., 1999) showed that plants grown in zero tillage were less severely damaged by these pests than plants grown in conventional tillage systems. Two factors may be responsible for this effect. Firstly, stubble from the previous crop, in shallow tillage systems, might constitute a barrier for egg laying and an unfavourable habitat for 
reproduction, whereas this stubble would be absent from ploughed plots. Secondly, deep ploughing drastically changes soil structure and is probably one of the most disturbing agricultural practices for soil fauna, and particularly for polyphagous carabids. Baquette and Hance (1997) compared three soil treatments — normal ploughing, light ploughing and no ploughing — and showed that the carabid species less abundant in deep ploughing systems became more numerous if reduced tillage or zero-tillage systems were used. Holland (2004) reviewed the positive effect of no-tillage systems on such polyphagous predators. However, Warner et al., (2003) concluded that the carabid Trechus quadristriatus may be an important predator of the eggs, and possibly of the larvae of cabbage stem flea beetle. They suggested that soil tillage for WOSR seed bed preparation occurs at a time when many T. quadristriatus individuals are emerging from the pupal stage. All these elements may account for the higher levels of larval infestation observed on ploughed plots than on plots with a shallow tillage regime in our study.

The effects of soil nitrogen content and sowing date on rape stem weevil levels have never been reported, as no study has considered the effects of cropping system on this pest. However, a study focusing on the interactions between C. napi (Gyll.) and C. pallidactilus (Marsh.) reported that egg-laying females of C. napi (Gyll.) showed a significant preference for plants with a larger stem diameter (Dechert and Ulber, 2004). This suggests that sowing date and soil nitrogen content may have a significant effect, via their effects on plant growth, modifying the individual attractiveness to the insects of the plants in a field.

Pollen beetle damage is particularly difficult to analyze because it depends on the timing of the attack, the growth stage of the crop (Nilsson, 1994) and damage compensation by the crop (Podlaska et al., 1996). Indeed, although plots in central France contained a high proportion of plants with larvae in 2004, the small number of adults per plant resulted in low bud abscission rates. Moreover, we have to note that bud abscission could be due to other factors such as frost. Therefore, the number of days with temperature below $0^{\circ} \mathrm{C}$ during flowering have been counted. Only the centre of France in 2001-2002 exhibited more than 2 days of temperatures below $-3^{\circ} \mathrm{C}$. It 
could partly explained the high number of blind stalks in this region that year. However, the very high proportion of blind stalks in the east of Paris might have been due to pollen beetle, because the temperature during flowering did not slow down under $-1^{\circ} \mathrm{C}$.

The negative effect of soil nitrogen content on pollen beetle damage has never before been reported. It may be related to the significant effect of nitrogen on plant vigour and, therefore, to the compensation of pollen beetle damage on new racemes (Podlaska et al., 1996). The differences in height between healthy and attacked plants may be related to the effect of main raceme growth stage on the spatial distribution of pollen beetle in WOSR fields, as described by Ferguson et al. (2003). Ferguson found that plant height was positively related to the growth stage of the main raceme and that the number of adult pollen beetles adults was positively related to the growth stage of the main raceme. Taller plants are therefore more attractive to this plant than shorter ones.

\subsection{Effect of surrounding environment}

The lower level of cabbage stem flea beetle and rape stem weevil attacks in regions with a high percentage of land under WOSR may result from the effects of insecticide applications on conventionally farmed fields around organic fields. Such insecticide applications in autumn and spring, in a region with a large percentage of land under conventional WOSR, could reduce the population of those pests. The effect of the percentage of land under conventional WOSR has been investigated by Zaller et al. (2006) and Url et al. (2006) and tended to show similar results except for pollen beetle.

In our study, the surrounding landscape was characterized in terms of whether there were hedges, trees and bushes in the field boundaries and in the landscape near the field. These sites constitute aestivation areas for cabbage stem flea beetle (Warner et al., 2003) and overwintering areas for pollen beetles (Büchi, 2002). The patterns of crop colonization by WOSR pests and by predators of these pests and other beneficial species can be accounted for by the distribution of over-wintering sites relative to the crop and wind direction (Ferguson et al., 2003; Warner et al., 2003; Warner et al., 2000). Hradetzky and Kromp (1997) counted flying insects around and within 
an organic rye field and described the diversity of these insects. Most families of insects tended to be concentrated around trees, which provide a source of food and shelter. Hedges and strips of woodland also provide shelter against the wind, providing suitable microclimatic conditions for flying insects. The antagonistic effects of the surrounding environment on the pests studied here may be accounted for by the diversity of plants in field boundaries. Büchi et al. (2002) observed that the effect of conservation strips on pollen beetle mortality due to parasitoids and predators differed for strips of meadow and wild flowers. Büchi suggested that the differences between these two types of conservation strip might be due to differences in the abundance of yellow flowers and cruciferous plants in the two types. Thus, the surrounding environment effect observed in this study may be due to the more diverse vegetation of field boundaries adjacent to woodland than of field boundaries adjacent to a (plain) field.

The opposite effects of woodland in regions with low and high percentages of land under WOSR may be accounted for by cropping system diversity and the application of insecticides to nearby conventionally farmed fields. Although organic farmers do not use insecticides, neighbouring conventional farmers do. In regions with low percentages of land under WOSR (Centre and South of France) — with more grassland in the Centre of France and more organic farming in Southern France with few cereals — the insecticide pressure is lower. This may have consequences for the beneficial fauna in habitats around fields, accounting for the lower occurrence of pests in the woodland landscape than in the plain landscape.

\section{General conclusions and implications for pest management}

We demonstrate here that crop management, including sowing date and plant density in particular, has a significant effect on pest occurrence. Nitrogen availability in the soil during the autumn also has an effect, probably due to the impact of nitrogen on plant vigour, which in turn affects sensitivity to pests. These results have important implications for organic WOSR growers. The antagonistic effects of date of sowing on cabbage stem flea beetle and root maggot levels make it necessary for growers to determine the ideal sowing date according to the most problematic pest 
in each field. Moreover, although ploughing increases cabbage stem flea beetle damage, it reduces the risk of weed infestation with cereals (Steinberg et al., 1999) or rape volunteers (Colbach et al., 2001) and some other weeds (Chauvel et al., 2001). High plant densities also seemed to be associated with low-level damage of all insects considered here. Nevertheless, the very small proportion of the variance accounted for by each practice suggested that changes in crop management practices cannot decrease pest incidence sufficiently, particularly in regions with large insect populations, such as the eastern Parisian Basin, and in systems without pesticides. Trap crops, which have been used to control stem-mining insects (Barari et al. 2005) and pollen beetle (Hokkanen, et al., 1986, 1989; Büchi, 1995; Cook et al., 2002 ; Cook et al., 2006a,b), may provide an alternative solution. Research into natural insecticides and cultivar resistance might help to reduce the massive yield losses caused by large populations of these pests. With the exception of the study of Husberg and Hokkanen (2001) on the effects of Metarhizium anisopliae on pollen beetle, few studies have focused on natural insecticides. However, many studies have investigated the susceptibilities of species and cultivars to infestations of root maggot (Dosdall et al., 1994, 2000) and pollen beetle (Bartlet et al., 1999, Ekbom et al., 2004), and may contribute to the development of cultivar resistance to pests.

These results confirm the general significance of landscape structures for pests. Although field boundaries may be considered to serve as a refuge for predators and parasitoids, we found that the presence of woodland around the field did not necessarily increase crop damage due to pests, despite the absence of insecticides in organic fields. This raises questions about the abundance and efficiency of predators in agro-ecosystems around fields in the presence of strong insecticide pressure. It may be possible to conserve or to restore natural predator populations by reducing insecticide use and manipulating the landscape around fields.

\section{Acknowlegements}

We would like to thank G. Grandeau, V. Tanneau, B. Fouillen, C. Soin, A. Chauveau, R. Baudoin and E. Castel for technical assistance. Y. Ballanger from Cetiom (Centre technique des oléagineux métropolitains) provided helpful expertise for the diagnosis of insect damage. We would also like to thank S. Tanis-Plant for editorial advice. Financial support for this study was provided by INRA (CIAB) and 
CETIOM. We would especially like to thank R. Reau, L. Quéré, C. Bonnemort, and D. Chollet, from Cetiom for their help in finding financial support and in setting up the network of farmers. 


\section{References}

Alford DV, Nilsson C., Ulber B. 2003. Insect pests in oilseed rape crops. In: D.V. Alford (ed), Biocontrol of oilseed rape pests. Blackwell Science, pp9-41.

Ballanger Y. Detourne D., Delorme R. Pinochet X. 2003. Difficultis to control pollen beetle (Meligethes aeneus F.) in Francerevealed by unusual high level infestations in winter rape fields. Proceeding of $11^{\text {th }}$ international rapeseed congress at the Royal Veterinary and agricultural University of Copenhaguen, DK, 6-10 July 2003. pp1048-1049.

Barari, H.; Cook, S. M; Clark, S. J., .; Williams, I. H., 2005. Effect of a turnip rape (Brassica rapa) trap crop on stem-mining pests and their parasitoids in winter oilseed rape (Brassica napus). BioControl 50 (1), 69-86

Bartlet, E.; Blight, M. M.; Pickett, J. A.; Smart, L. E.; Turner, G.; Woodcock, C. M., 2004. Orientation and feeding responses of the pollen beetle, Meligethes aeneus, to candytuft, Iberis amara. Journal of Chemical Ecology 30 (5), 913-925

Bartlet, E.; Mithen, R.; Clark, S. J., 1996. Feeding of the cabbage stem flea beetle Psylliodes chrysocephala on high and low glucosinolate cultivars of oilseed rape. Entomologia Experimentalis et Applicata 80 (1), 87-89 1996.

Billqvist A.; Ekbom B.2001a. The influence of host plant species on parasitism of pollen beetles (Meligethes spp.) by Phradis morionellus. Entomologia Experimentalis et Applicata 98 (1), $41-47$

Billqvist, A.; Ekbom, B., 2001b. Effects of host plant species on the interaction between the parasitic wasp Diospilus capito and pollen beetles (Meligethes spp.). Agricultural and Forest Entomology 3 (2), 147152.

Borg, A.., Ekbom, B., 1996. Characteristics of oviposition behaviour of the pollen beetle, Meligethes aeneus on four different host plants. Entomologia Experimentalis et Applicata 81 (3), 277-284.

Büchi, R., 2002. Mortality of pollen beetle (Meligethes spp) larvae due to predators and parasitoids in rape fields and the effect of conservation strips. Agriculture, Ecosystems and Environment 90, 255-263.

Butt TM, Barrisever M, Drummond J, Schuler TH, Tillemans FT, Wilding N. 1992. Pathogenicity of the entomogenous, hyphomycete fungus, Metarhizium anisopliae against the chrysomelid beetles Psylliodes chrysocepala and Phaedon cochleariae. Biocontrol Science and Technology 2:327-34

Butt TM, Carreck NL, Ibrahim L, Williams IH. 1998. Honey-bee-mediated infection of pollen beetle (Meligethes aeneus Fab.) by the insect-pathogenic fungus, Metarhizium anisopliae. Biochemical Science and Technology8:533-8

Cetiom, 1994. Guide de l'expérimentateur CETIOM Paris.

Cetiom, 1998. Colza d'hiver-Le contexte économique, les techniques culturales et les débouchésBrochure annuelle. CETIOM. Paris, 40p.

Chauvel, B., Guillemin, J. P., Colbach, N., Gasquez, J., 2001. Evaluation of cropping systems for management of herbicide-resistant populations of blackgrass (Alopecurus myosuroides Huds.). Crop Protection 20 (2), 127-137. 
Colbach, N., Clermont-Dauphin, C., Meynard, J. M., 2001. GENESYS: a model of the influence of cropping system on gene escape from herbicide tolerant rapeseed crops to rape volunteers. I. Temporal evolution of a population of rapeseed volunteers in a field. Agriculture, Ecosystems \& Environment 83 (3), 235-253.

Cook SM, Murray DA, Williams IH. 2004. Do pollen beetles need pollen? The effect of pollen on oviposition, survival, and development of a flower-feeding herbivore. Ecological Entomology 29: 164-73

Cook SM, Smart LE, Martin JL, Murray DA, Watts NP, Williams IH. 2006a. Exploitation of host plant preferences in pest management strategies for oilseed rape (Brassica napus). Entomologia Experimentalis Et Applicata 119: 221-9

Cook, S. M., L. E. Smart, M. P. Skellern, N. P., Watts, and I. H. Williams, 2006b. Development of a push-pull strategy for control of oilseed rape pests. Proceedings of an Internationl Symposium on integrated management in oilseed rape held at the University of Göttingen in Göttingen, Germany UK, 2-5 April 2006. CD rom.

Cook, S. M., Smart, L. E., Potting, R. J. P., Bartlet E., Martin, J. L., Murray, D. A., Watts, N. P., Williams, I. H., 2002. Turnip rape (Brassica rapa) as a trap crop to protect oilseed rape (Brassica napus) from infestation by insect pests: potential and mechanisms of action. The BCPC Conference: Pests and diseases, Volumes 1 and 2. Proceedings of an international conference held at the Brighton Hilton Metropole Hotel, Brighton, UK, 18-21 November 2002. pp 569-574.

Dechert, G., Ulber, B., 2004. Interactions between the stem-mining weevils Ceutorhynchus napi Gyll. and Ceutorhynchus pallidactylus (Marsh.) (Coleoptera: Curculionidae) in oilseed rape. Agricultural and Forest Entomology 6 (3), 193-198.

Dennis, P., 1992. Insect diversity and farm woodland pattern. Report - Institute of Terrestrial Ecology, 24-27.

Dosdall L. M., Florence L. Z., Conway P. M., 1998. Tillage regime, row spacing, and seeding rate influence infestations of root maggots (Delia spp.) (Diptera: Anthomyiidae) in canola. Canadian Journal of Plant Science 78 (4), 671-681.

Dosdall L. M., Herbut M. J., Cowle N. T., 1994. Susceptibilities of species and cultivars of canola and mustard to infestation by root maggots (Delia spp.) (Diptera: Anthomyiidae). Canadian Entomologist $126(2), 251-260$.

Dosdall, L. M., Dolinski, M.G., Cowle, N. T., Conway, P.M., 1999. The effect of tillage regime, row spacing, and seeding rate on feeding damage by flea beetles, Phyllotreta spp. (Coleoptera: Chrysomelidae), in canola in central Alberta, Canada. Crop Protection 18 (3), 217-224.

Dosdall, L. M., Good, A.., Keddie, B. A.., Ekuere, U., Stringam, G., 2000. Identification and evaluation of root maggot (Delia spp.) (Diptera: Anthomyiidae) resistance within Brassicaceae. Crop Protection 19 (4), 247-253

Dosdall, L. M., Herbut, M. J., Cowle, N. T., Micklich, T. M. 1996. The effect of seeding date and plant density on infestations of root maggots, Delia spp. (Diptera: Anthomyiidae), in canola. Canadian Journal of Plant Science 76 (1), 169-177. 
Ekbom B, Kuusk AK. 2001. Pollen beetles (Meligethes aeneus) and resistance against pyrethroids. Vaxtskyddsnotiser65:39-42

Ferguson, A. W., Klukowski, Z., Walczak, B., Clark, S. J., Mugglestone, M. A., Perry, J. N., Williams, I. H., 2003. Spatial distribution of pest insects in oilseed rape: implications for integrated pest management. Agriculture, Ecosystems \& Environment 95 (1/3), 509-521

Franck T. 1998. Slug damage and numbers of the slug pests, Arion lusitanicus and Deroceras reticulatum, in oilseed rape grown beside sown wildflower strips. Agriculture Ecosystems and Environment $67,67-78$.

Hansen LM. 2003. Insecticide-resistant pollen beetles (Meligethes aeneus F) found in Danish oilseed rape (Brassica napus L) fields. Pest Management Science 59: 1057-9 7.Hokkanen H, Husberg GB, Soderblom M. 1988. Natural enemy conservation for the integrated control of the rape blossom beetle Meligethes aeneus F. Annales Agriculturae Fenniae 27: 281-94

Hokkanen H. M. T., 1989, Biological and agrotechnical control of the rape blossom beetle Meligethes aeneus (Coleoptera, Nitidulidae). Acta Entomologica Fennica 53, 25-29

Hokkanen H., Granlund H., Husberg G. B., 1986. Trap crops used successfully to control Meligethes aeneus (Col., Nitidulidae), the rape blossom beetle. Annales Entomologici Fennici 52 (4), 115-120

Hopkins R J, Ekbom B (1999).The pollen beetle, Meligethes aeneus, changes egg production rate to match host quality. Oecologia 120, 274-278.

Husberg, G. B., Hokkanen, H. M. T. 2001 Effects of Metarhizium anisopliae on the pollen beetle Meligethes aeneus and its parasitoids Phradis morionellus and Diospilus capito. BioControl 46 (3), 261-273

Lancashire PD, Bleiholder H, Vandenboom T, Langeluddeke P, Stauss R, et al. 1991. A uniform decimal code for growth stages of crops and weeds. Annals of Applied Biology 119: 561-601

Nielsen O., Philipsen H. 2005. Susceptibility of Meligethes spp. and Dasyneura brassicae to entomopathogenic nematodes during pupation in soil. BioControl 50 (4), 623-634

Nilsson C., 1994. Pollen beetles (Meligethes spp.) in oil seed rape crops (Brassica napus L.): biological interactions and crop losses. , PhD thesis , 308 pp. 1994

Stinner, B. R., House, G. J., 1990. Arthropods and other invertebrates in conservation-tillage agriculture. Annual Review of Entomology 35, 299-318 1990

Tscharntke T, Klein AM, Kruess A, Steffan-Dewenter I, Thies C. 2005. Landscape perspectives on agricultural intensification and biodiversity - ecosystem service management. Ecology Letters 8: 857-74

Ulber, B., 2000. Bibliography of parasitoid species and levels of parasitism of rape stem weevil Ceutorhynchus napi Gyll. and cabbage stem weevil Ceutorhynchus pallidactylus (Mrsh.). Editor(s): Paul, V. H., Foller, I., Evans, N., Williams, I. Bulletin OILB/SROP 23 (6), 131-134.

Url C., Zaller, J. G., Drapela T., Moser and D., Frank T., 2006. Pollen beetles and landscape complexity: pest abundance, parasitisation and damage onoilseed rape Proceedings of Internationl Symposium on integrated management in oilseed rape held at the University of Göttingen in Göttingen , Germany UK, 2-5 April 2006. CD rom 
Warner, D. J., Allen-Williams, L. J., Ferguson, A. W., Williams, I. H., 2000. Pest-predator spatial relationships in winter rape: implications for integrated crop management. Pest Management Science 56 (11), 977-982.

Warner, D. J., Allen-Williams, L. J., Warrington, S., Ferguson, A. W., Williams, I. H., 2003. Mapping, characterisation, and comparison of the spatio-temporal distributions of cabbage stem flea beetle (Psylliodes chrysocephala), carabids, and Collembola in a crop of winter oilseed rape (Brassica napus). Entomologia Experimentalis et Applicata 109 (3) , 225-234

Williams, I H., 2006. Integrating biological control within IPM for winter oilseed rape in Europe: an overview of the MASTER project. Proceedings of an Internationl Symposium on integrated management in oilseed rape held at the University of Göttingen in Göttingen, Germany UK, 2-5 April 2006. CD rom

Williams, I. H., Buchs, W., Hokkanen, H., Menzler-Hokkanen, I., Johnen, A., Klukowski, Z., Luik, A., Nilsson, C., Ulber, B. 2002. MASTER: Management Strategies for European Rape pests - a new EU Project. The BCPC Conference: Pests and diseases, Volumes 1 and 2. Proceedings of an international conference held at the Brighton Hilton Metropole Hotel, Brighton, UK, 18-21 November 2002 , 641-646

Zalle r J. G., Drapela G., Moser, T., D,C., Url and T., Frank. 2006. Species-specific responses of oilseed rape pests to different elements of landscape complexity. Proceedings of Internationl Symposium on integrated management in oilseed rape held at the University of Göttingen in Göttingen , Germany UK, 2-5 April 2006. CD rom. 


\section{Figure captions}

Figure 1: Effect of crop management : relationships between sowing date on root maggot damage (A) and attacks of cabbage stem flea beetle (Psylliodes chrysocephala L ) (B). Effect of soil tillage regime on the proportion of plants attacked by cabbage stem flea beetle (C). Means and $95 \%$ confidence intervals for the selected plots.

Figure 2: Comparison within plots of collar diameter (A) between healthy plants and plants attacked by root maggot (Delia radicum L.). Comparison within plots of the heights of healthy plants and plants attacked by (B) pollen beetle (Meligethes aeneus $F$.). Each point corresponds to the mean of 15 plants sampled from a microplot. The observations of blossom pollen beetle larvae in spring illustrated in B were made in 2001, for only 10 of the 56 plots.

Figure 3: Effect of surrounding field environment on the proportion of plants attacked by Psylliodes chrysocephala L (A), Delia radicum L (B), Ceuthorhynchus napi Gyl (C.), and Meligethes aeneus F. (D). Means and $95 \%$ confidence intervals for the selected plots. 
Figure 1
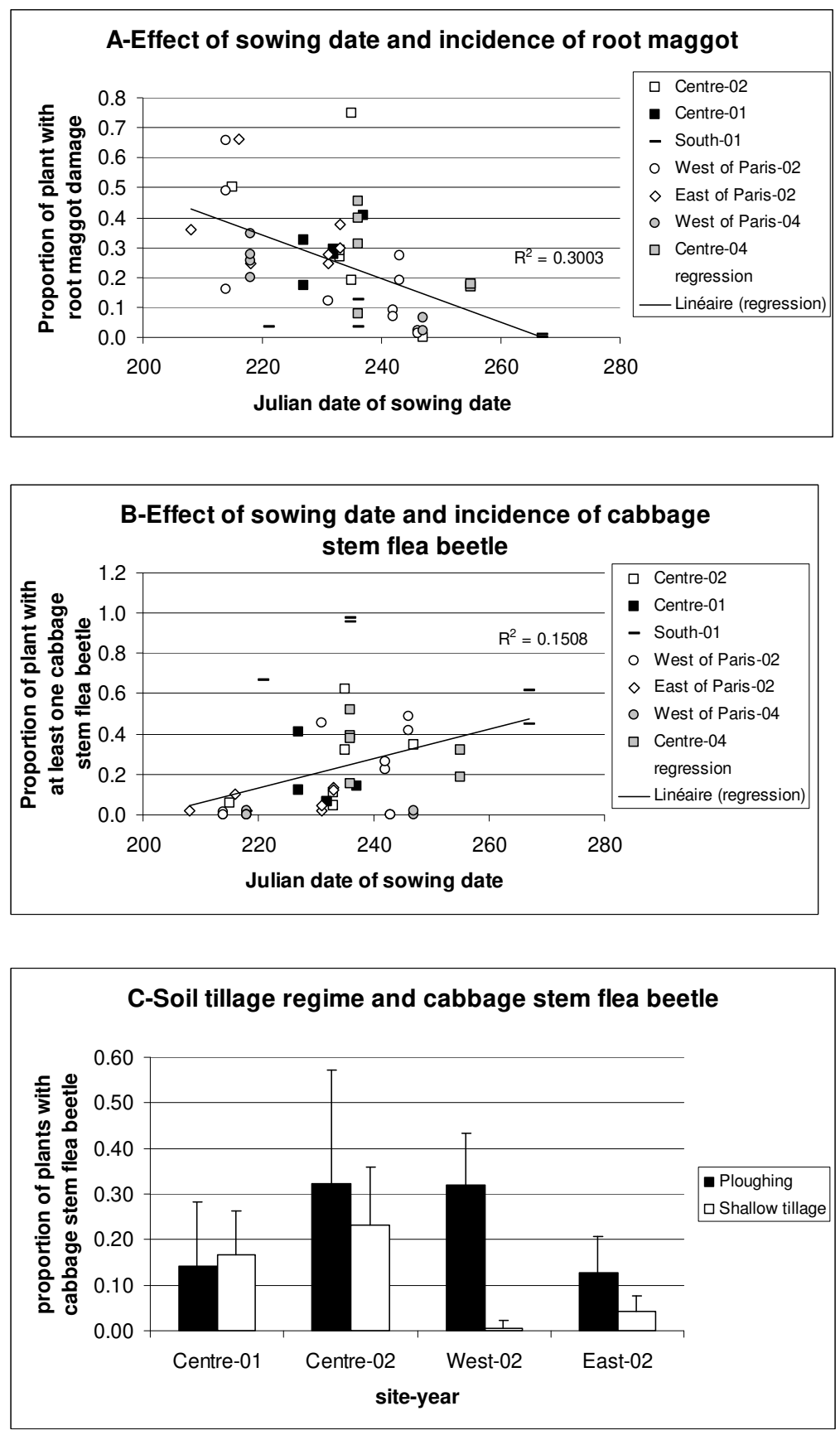
Figure2
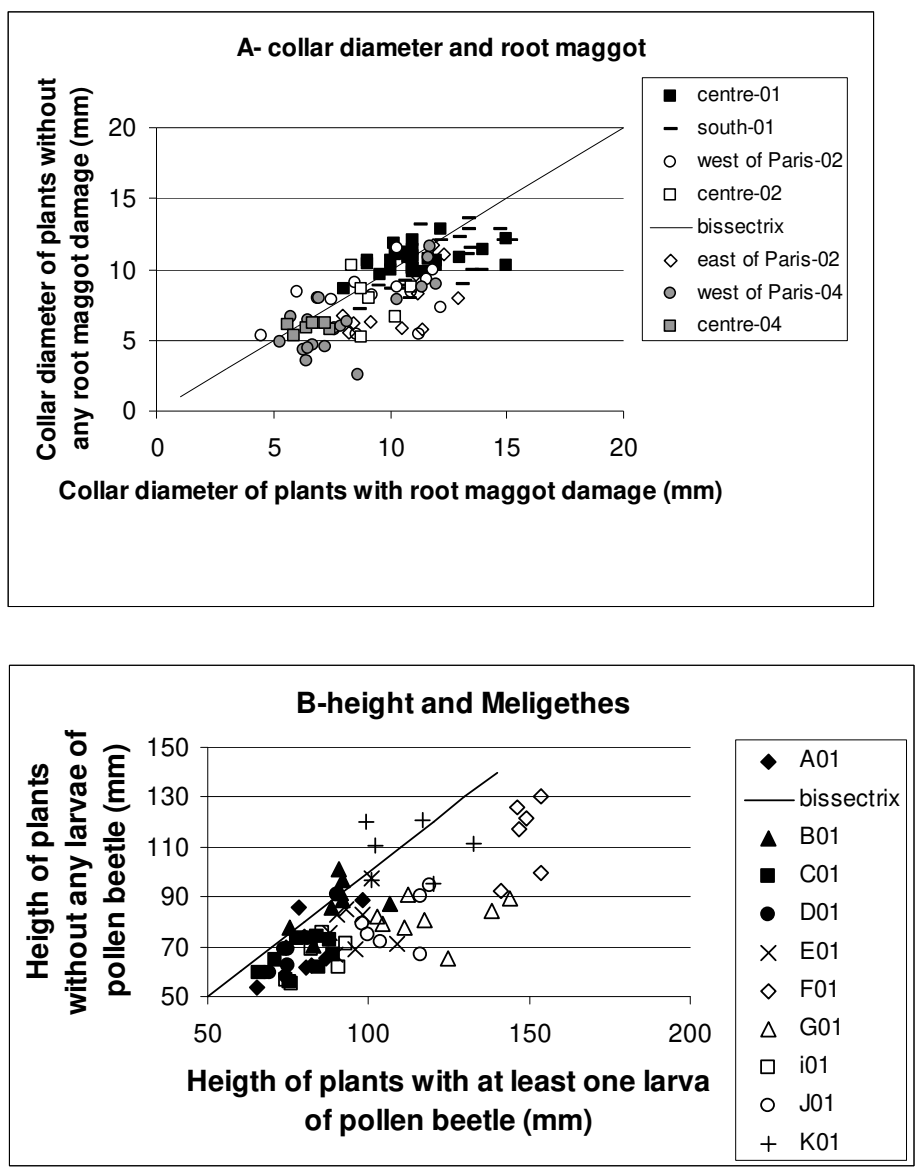
Figure 3
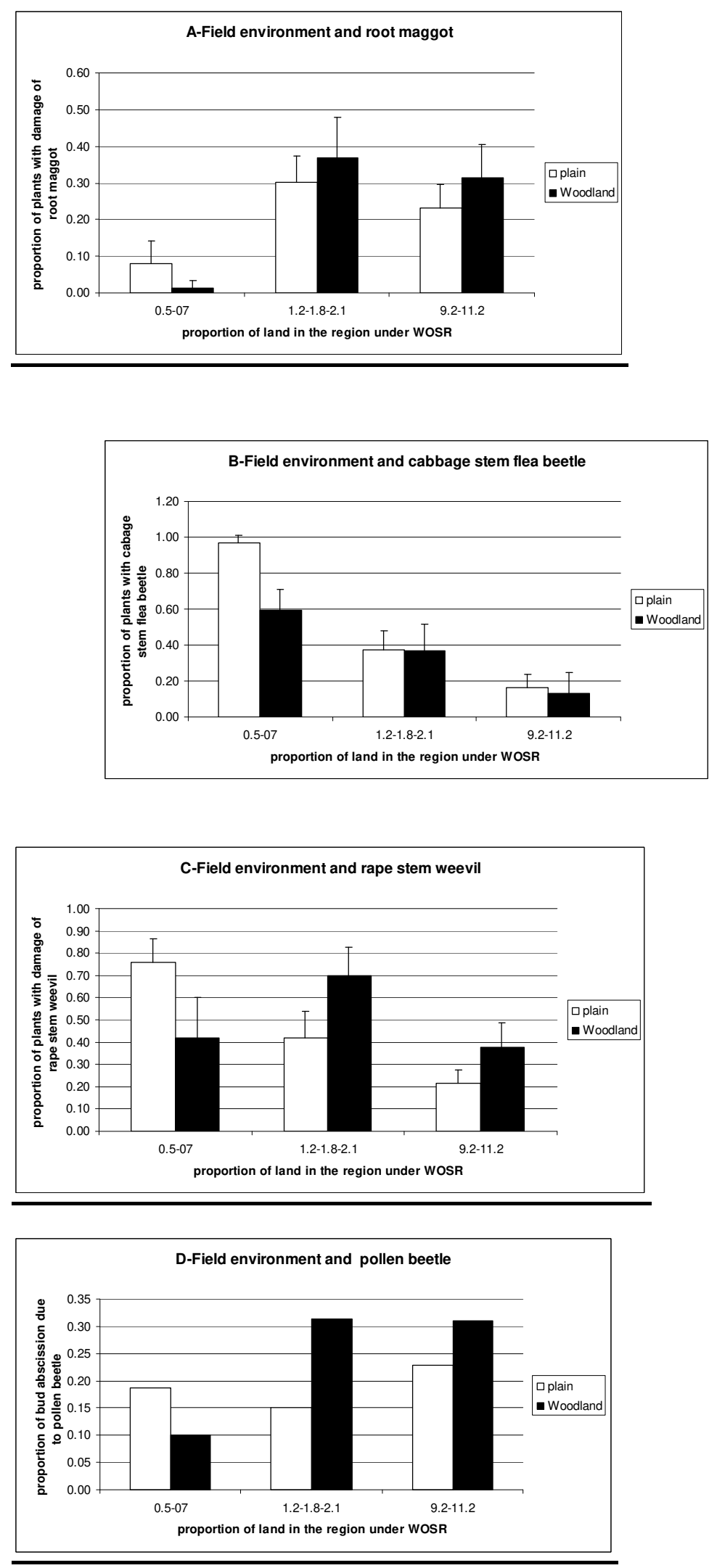


\section{Tables}

Table 1: Description of cropping systems and habitat classification for each farm field in the network. Fields are designated by the first letter. Plots were designated with a letter-figure-letter code, in which the first letter is the field code and the figure, a composite of the year code (01, 02, 04 for 2001, 2002 and 2004 respectively) and the little letter the crop management code. The crop management differed in terms of sowing date, plant density, soil tillage and row spacing and are detailed in the table 2 . Not all the plots were studied every year.

\begin{tabular}{|c|c|c|c|c|c|c|c|}
\hline Farm field & $\begin{array}{l}\text { Region - } \\
\text { name of } \\
\text { French } \\
\text { département }\end{array}$ & $\begin{array}{c}\text { Crop } \\
\text { preceding } \\
\text { WOSR }\end{array}$ & Cultivar & Sowing date + & $\begin{array}{c}\text { Plant } \\
\text { density at } \\
\text { early } \\
\text { winter* }\end{array}$ & $\begin{array}{l}\text { Nitrogen } \\
\text { in soil one } \\
\text { month } \\
\text { after } \\
\text { sowing } \\
(\mathrm{kg} / \mathrm{ha})^{*}\end{array}$ & $\begin{array}{c}\text { Habitat } \\
\text { classification }\end{array}$ \\
\hline $\mathrm{A}_{01-\mathrm{b}}$ & Centre of & Pea & Navajo & $08 / 21 / 2000$ & 64 & 57 & $\mathrm{P}$ \\
\hline $\mathrm{B}_{01-\mathrm{b}}$ & France - Puy & Pea & Navajo & $08 / 21 / 2000$ & 77 & 94 & $\mathrm{P}$ \\
\hline $\mathrm{B}_{02-\mathrm{a}-\mathrm{c}-\mathrm{d}}$ & de Dôme & Pea & Pollen & $08 / 7-25 / 2001$ & $38-87$ & $112-182$ & $\mathrm{P}$ \\
\hline $\mathrm{B}_{04-\mathrm{c}-\mathrm{d}-\mathrm{e}-\mathrm{f}-\mathrm{g}-\mathrm{h}} *$ & & Pea & Mendel & 08/15/03;09/13/03 & $45-80$ & $127-207$ & $\mathrm{P}$ \\
\hline $\mathrm{C}_{01-\mathrm{a}}$ & & Barley & Navajo & $08 / 16 / 2000$ & 67 & 73 & $\mathrm{~W}$ \\
\hline $\mathrm{D}_{01-\mathrm{a}}$ & & Barley & Navajo & 08/16/2000 & 66 & 73 & $\mathrm{~W}$ \\
\hline$E_{01-\mathrm{g}}$ & & Wheat & Navajo & 08/26/2000 & 81 & 84 & $\mathrm{~W}$ \\
\hline $\mathrm{E}_{02 \text {-a-b-h }}$ & & Wheat & Pollen & 08/18/01;09/08/01 & $60-76-$ & $129-167$ & $\mathrm{~W}$ \\
\hline $\mathrm{I}_{01-\mathrm{g}}$ & South of & Barley & Navajo & $08 / 25 / 2000$ & 73 & 176 & $\mathrm{P}$ \\
\hline $\mathrm{J}_{01-\mathrm{g}}$ & France & Fallow & Navajo & $08 / 25 / 2000$ & 76 & 133 & $\mathrm{P}$ \\
\hline $\mathrm{K}_{01-\mathrm{e}}$ & Drôme & Fallow & Navajo & $08 / 10 / 2000$ & 50 & 69 & $\mathrm{~W}$ \\
\hline $\mathrm{L}_{02-b-c-h}$ & West of Paris & Wheat & Pollen & 08/23/01;09/5/01 & $40-71-$ & $108-153$ & $\mathrm{P}$ \\
\hline $\mathrm{L}_{04-c-d-e-f-g-h}$ & - Eure et Loir & Wheat & Mendel & 08/07/03;09/05/03 & $59-101$ & $54-202$ & $\mathrm{P}$ \\
\hline $\mathrm{M}_{02-\mathrm{a}-\mathrm{c}-\mathrm{d}}$ & & $\mathrm{Pea} /$ triticale & Pollen & 08/03/01;08/30/01 & $30-52$ & $108-137$ & $\mathrm{~W}$ \\
\hline $\mathrm{N}_{02 \text {-a-c-d-e }}$ & & Triticale & Pollen & 08/02/01;08/31/01 & $22-66$ & $114-116$ & $\mathrm{P}$ \\
\hline $\mathrm{T}_{04-\mathrm{c}-\mathrm{g}}$ & Eure & Wheat & Mendel & $08 / 28 / 2003$ & $60-50$ & 72 & $\mathrm{~W}$ \\
\hline $\mathrm{U}_{04-\mathrm{c}-\mathrm{g}}$ & Eure & Wheat & Mendel & $08 / 25 / 2003$ & $57-55$ & $152-176$ & $\mathrm{P}$ \\
\hline $\mathrm{O}_{02-\mathrm{a}}$ & East of Paris - & Triticale & Pollen & $07 / 29 / 01$ & 26 & 133 & $\mathrm{~W}$ \\
\hline $\mathrm{P}_{02 \text {-a-c-d }}$ & Yonne & Wheat & Pollen & 08/08/01;08/25 & $63-83$ & $86-132$ & $\mathrm{~W}$ \\
\hline $\mathrm{Q}_{02-a-b-d}$ & & Barley & Pollen & 07/26/01;08/25/01 & $91-95$ & $51-66$ & $\mathrm{P}$ \\
\hline $\mathrm{R}_{04-\mathrm{b}-\mathrm{c}-\mathrm{d}-\mathrm{g}-\mathrm{h}}$ & & Lentil & Mendel & 08/27/2003;3/09 & $70-72$ & $203-232$ & $\mathrm{P}$ \\
\hline $\mathrm{S}_{04-\mathrm{c}-\mathrm{d}-\mathrm{g}-\mathrm{h}}$ & & Wheat & Mendel & 08/26/2003;3/09 & $46-52$ & $267-335$ & $\mathrm{~W}$ \\
\hline
\end{tabular}

+ The date of sowing is given as month/day/year

*The values for plant density and soil nitrogen correspond to the range of values obtained. W: "Woodland" landscape; P: "Plain" landscape. 
Table 2: Description of the crop management for each plot in the network

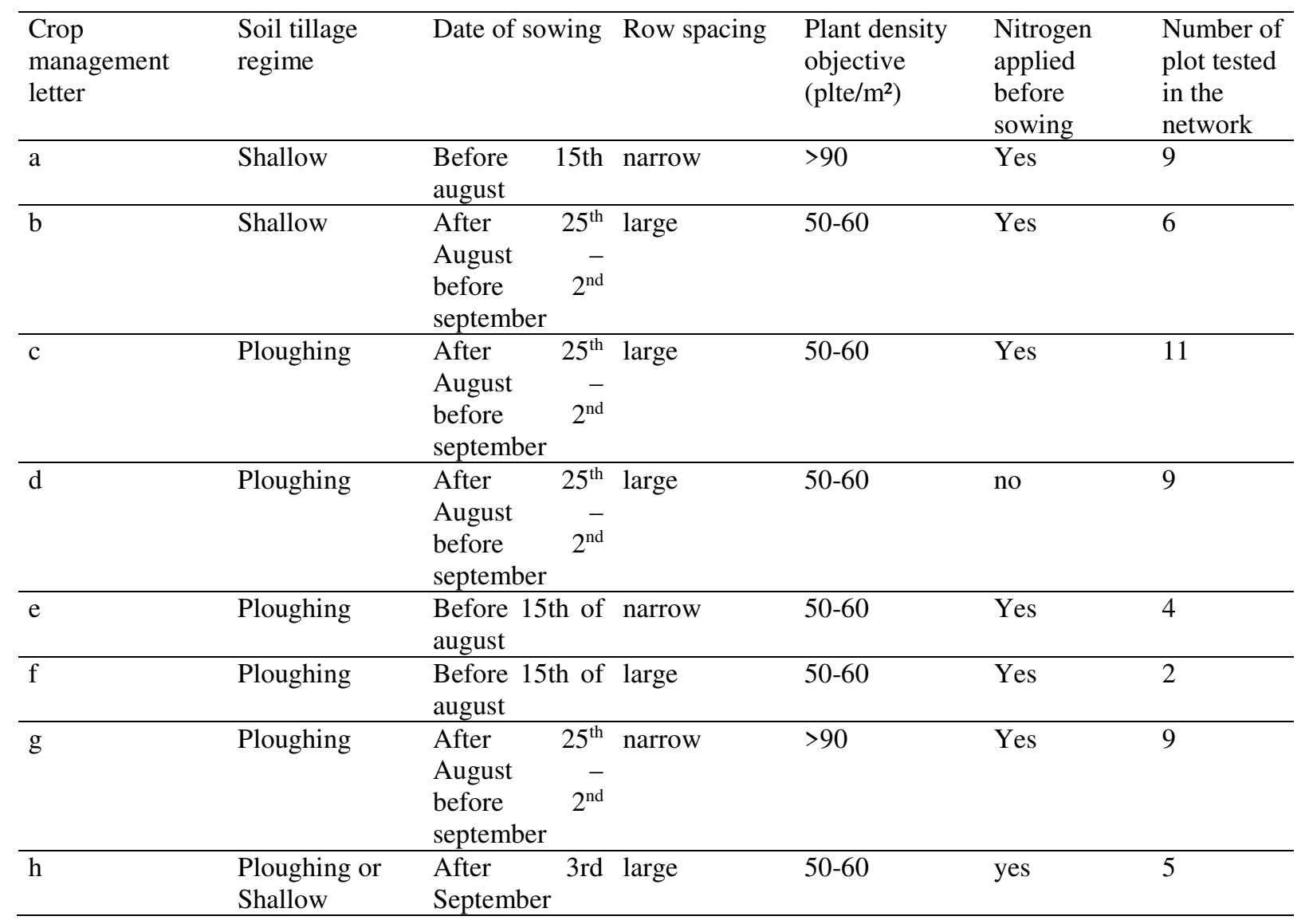


Table 3. Mean occurrence of pests and damage by region and year: proportion of plants with damage due to root maggot larvae (Delia radicum L.); proportion of plants with at least one larva or damage due to cabbage stem flea beetle (Psylliodes chrysocephala L..); proportion of plants with at least one larva or damage due to rape stem weevil (Ceuthorhynchus napi Gyll.); proportion of plants with pollen beetle (Meligethes aeneus F. ) adults or larvae at flowering; number of pollen beetle adults per plant; proportion of blind stalks due to bud abscission.

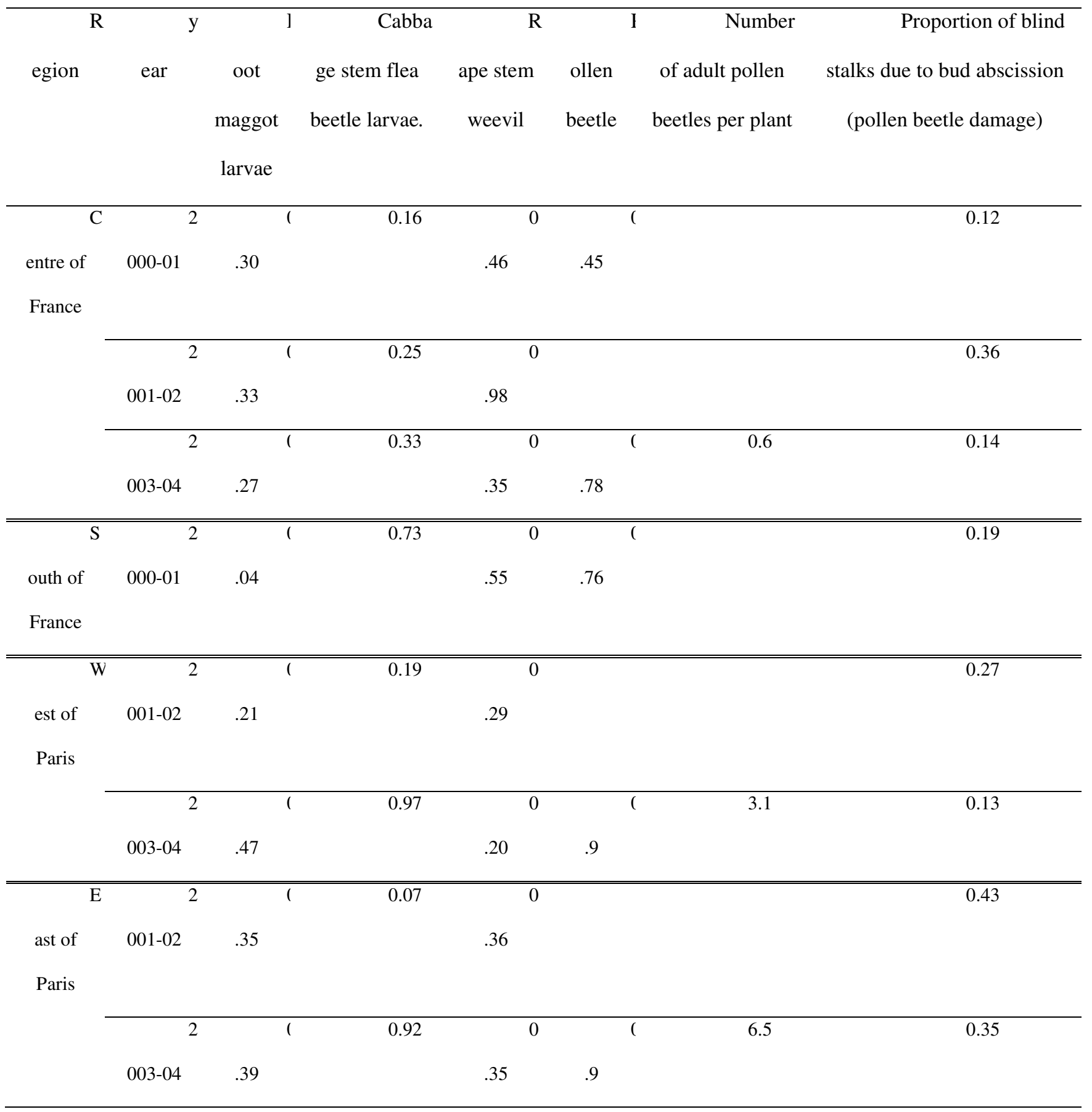


Table 4: Effect of sowing date, plant density, soil tillage regime and available nitrogen on pest damage due to root maggot and cabbage stem flea beetle larvae, rape stem weevil and pollen beetle adults: F-value, probability, proportion of variance explained, and sign of the regression coefficient obtained by Co-ANOVA

\begin{tabular}{|c|c|c|c|c|c|c|c|c|}
\hline \multirow[t]{3}{*}{$\begin{array}{c}\text { Crop } \\
\text { management }\end{array}$} & \multicolumn{2}{|c|}{$\begin{array}{c}\% \text { plants with } \\
\text { symptoms of root } \\
\text { maggot attacks in early } \\
\text { winter }\end{array}$} & \multicolumn{2}{|c|}{$\begin{array}{l}\% \text { plants with at } \\
\text { least one cabbage stem } \\
\text { flea beetle larva in early }\end{array}$} & \multicolumn{2}{|c|}{$\begin{array}{c}\% \text { plants with } \\
\text { symptoms of rape } \\
\text { stem weevil attacks at } \\
\text { flowering }\end{array}$} & \multicolumn{2}{|c|}{$\begin{array}{l}\text { \% blind stalks due to } \\
\text { bud abscission (pollen } \\
\text { beetle) }\end{array}$} \\
\hline & \multicolumn{8}{|c|}{ winter } \\
\hline & $\begin{array}{l}\text { F Value } \\
\text { and } \\
\text { probability }\end{array}$ & $\begin{array}{l}\text { proportion } \\
\text { of } \\
\text { variance, } \\
\text { regression } \\
\text { sign }\end{array}$ & $\begin{array}{l}\text { F Value } \\
\text { and } \\
\text { probability }\end{array}$ & $\begin{array}{l}\text { proportion } \\
\text { of } \\
\text { variance, } \\
\text { regression } \\
\text { sign }\end{array}$ & $\begin{array}{l}\text { F Value } \\
\text { and } \\
\text { probability }\end{array}$ & $\begin{array}{l}\text { proportion } \\
\text { of } \\
\text { variance, } \\
\text { regression } \\
\text { sign }\end{array}$ & $\begin{array}{l}\text { F Value } \\
\text { and } \\
\text { probability }\end{array}$ & $\begin{array}{l}\text { proportion } \\
\text { of } \\
\text { variance, } \\
\text { regression } \\
\quad \text { sign }\end{array}$ \\
\hline Sowing date & $* * *$ & $9.1(-)$ & $* * *$ & $7.6(+)$ & $* * *$ & $2.4(+)$ & NS & \\
\hline $\begin{array}{l}\text { Soil tillage } \\
\text { regime }\end{array}$ & $*$ & 1.4 & $*$ & 0.02 & Not tested & & Not tested & \\
\hline $\begin{array}{l}\text { Plant density } \\
\text { in early } \\
\text { winter }\end{array}$ & $* *$ & $1.0(-)$ & $* *$ & $0.5(-)$ & $*$ & $1.3(-)$ & $* *$ & $1.4(-)$ \\
\hline $\begin{array}{l}\text { Soil nitrogen } \\
\text { content at } \\
\text { sowing }\end{array}$ & NS & & $* * *$ & $3.9(+)$ & $*$ & $0.6(-)$ & $* * *$ & $3.5(-)$ \\
\hline Site-year & $* * *$ & 8.1 & $* * *$ & 31.9 & $* * *$ & 63.5 & $* * *$ & 46.0 \\
\hline
\end{tabular}

$* \mathrm{P}<0.05 ; * * \mathrm{P}<0.01 ; * * * \mathrm{P}<0.001 ; \mathrm{NS}: \mathrm{P}>0.05$ 
Table 5: Effect of field environment on damage due to root maggot, cabbage stem flea beetle larvae, rape stem weevil and pollen beetle: F-value, probability, proportion of variance explained, and sign of the regression coefficient obtained by Co-ANOVA.

\begin{tabular}{|c|c|c|c|c|}
\hline $\begin{array}{l}\text { Environment and } \\
\text { crop management }\end{array}$ & $\begin{array}{c}\% \text { plants with } \\
\text { symptoms of root } \\
\text { maggot attacks in early } \\
\text { winter }\end{array}$ & $\begin{array}{l}\% \text { plants with } \\
\text { at least one cabbage } \\
\text { stem flea beetle larva in } \\
\text { early winter }\end{array}$ & $\begin{array}{c}\% \text { plants with } \\
\text { symptoms of rape stem } \\
\text { weevil attacks at } \\
\text { flowering }\end{array}$ & $\begin{array}{l}\% \text { blind stalks due } \\
\text { to bud abscission } \\
\text { (pollen beetle) }\end{array}$ \\
\hline Year & $* * * 13.2$ & $* 0.3$ & $* * * 18.9$ & $* * * 5.7$ \\
\hline $\begin{array}{c}\text { \% of land under } \\
\text { WOSR in the } \\
\text { region }\end{array}$ & $* * 3.5$ & $* * * 25.3$ & $* * * 4.5$ & $* * 2.3$ \\
\hline $\begin{array}{l}\text { Environment } \\
\text { surrounding the } \\
\text { field }\end{array}$ & $* * * 28.3$ & $* 1.8$ & $* * 0.9$ & $* * * 48.4$ \\
\hline $\begin{array}{l}\text { Plant density in } \\
\text { early winter }\end{array}$ & $* 0.6(-)$ & $* * 1.9(-)$ & $* * 2.3(-)$ & NS \\
\hline $\begin{array}{l}\text { Soil nitrogen } \\
\text { content at sowing }\end{array}$ & Not tested & $* * * 9.8(+)$ & $7.8(-)$ & $* * * 4(-)$ \\
\hline
\end{tabular}

$* \mathrm{P}<0.05 ; * * \mathrm{P}<0.01 ; * * * \mathrm{P}<0.001 ; \mathrm{NS}: \mathrm{P}>0.05$ 